\title{
Kinetic study of serum penicillin concentrations after single doses of benzathine and benethamine penicillins in young and old people
}

\author{
P COllart, M POITEVIN, A Milovanovic, A HERlin, AND J DUREL \\ From the Alfred Fournier Institute, Paris, France
}

SUMMARY In a comparative kinetic study of the serum concentrations of two penicillin complexes-medium-long-acting (benethamine penicillin) and long-acting (benzathine bipenicillin) - after a single injection in young adults and elderly people, the following results were confirmed statistically: (a) age was a major factor in the variations in serum penicillin concentrations and in their persistence in the serum; (b) the penicillin was absorbed faster in young than in elderly subjects even when a long-acting complex was used; (c) serum concentrations below the level regarded as lethal for treponemes appeared much earlier and more frequently in young than in old people; and (d) the bioequivalence between penicillin preparations could not be estimated solely from the number of units of the agent used but from the bioavailability of the chosen formulation.

Thus a uniform and standard penicillin dosage allowing no safety margin may help in the superficial healing of a syphilitic chancre or the resolution of a roseola but it will certainly be insufficient to kill Treponema pallidum. It seems essential therefore to provide an antibiotic cover at high dosage over a long period of time.

\section{Introduction}

Penicillin has long been the drug of choice for the treatment of syphilis, ${ }^{2}$ and many penicillin preparations have been made available. ${ }^{3}$ However, in the absence of properly compiled statistics ${ }^{4}$ over an adequate period to assess the results of therapy, many specialists have tended to base the dosage solely on the number of international units (IU). ${ }^{2}$

It would be interesting, without attempting to carry out an exhaustive study on the kinetics of excretion of medium-acting and long-acting combinations of penicillin containing either benethamine penicillin ${ }^{5-7}$ or benzathine bipenicillin, ${ }^{8-10}$ to compare their bioavailability after an intramuscular injection of a single standard dose, the choice of dosages being based on generally acceptable standards for the treatment of syphilis. ${ }^{2} 9$ 11-17

At present there are many factors capable of affecting the elimination of penicillin. The influence of age on the bioavailability of these products was

Address for reprints: Dr P Collart, Institut Alfred Fournier, 25 Boulevard Saint-Jacques, 75014 Paris, France

Received for publication 3 October 1978 chosen for this study; in fact, age modifies many physiological functions but its influence on the kinetics of drugs is as yet almost unknown. ${ }^{18}$

Investigations have been performed on penicillins with a short action. ${ }^{19-23}$ No comparative study however has been carried out on delayed-acting penicillins to demonstrate (a) the degree to which a drug becomes available to the systemic circulation and the rate at which this occurs (bioavailability) in relation to age (that is, how the clinical effectiveness of a drug can be correlated with the measurements of its serum concentration after administration and the time-dose relationship) ${ }^{24-26}$; and (b) the influence of the pharmaceutical preparation on the intensity and the period of action of the agent in relation to age. To provide a better basis for the statistical analysis of our results, the values were weighted in terms of plasma volume using the nomogram of Dagher et $a l,{ }^{27}$ in which the weight, age, and sex of the subjects are considered.

The aim of this paper is not to propose a therapeutic plan but, considering the results obtained, to present data which will help doctors to choose and adjust doses for each individual patient in the treatment of syphilis. ${ }^{28}$ 


\section{Subjects and methods}

\section{CHOICE OF SUBJECTS}

Four groups of healthy subjects were selected for the study ${ }^{29}$ :

Group Ia, consisting of young adults (20 male, mean age $20 \cdot 5 \pm 1 \cdot 2$ years, mean weight $63 \cdot 8 \pm 6 \cdot 5 \mathrm{~kg}$ ) given benethamine penicillin complex;

Group $1 b$, consisting of young adults (14 male and one female, mean age $22 \pm 2 \cdot 8$ years, mean weight $64 \cdot 8 \pm 6 \cdot 5 \mathrm{~kg}$ ) given benzathine bipenicillin complex; Group $2 a$, consisting of elderly subjects (24 female and 12 male, mean age $75 \pm 8 \cdot 4$ years, mean weight $58 \cdot 1 \pm 12 \cdot 9 \mathrm{~kg}$ ) given benethamine penicillin complex; and

Group $2 b$, consisting of elderly subjects (20 female and five male, mean age $76 \pm 9 \cdot 3$ years, mean weight $58 \cdot 7 \pm 10 \cdot 5 \mathrm{~kg}$ ) given benzathine penicillin complex.

Renal function was systematically checked by measuring the creatinine clearance, which was normal.

The weight and urinary output of all subjects were recorded and investigations were carried out to ensure that none of them received any other therapy during the test period which might affect the serum penicillin concentrations.

CHOICE OF PENICILLIN

Two types of penicillin were selected:

(a) a complex with medium-long action, benethamine penicillin, composed of benethamine penicillin $600000 \mathrm{IU}$ and penicillin G sodium 400000 IU; and

(b) a complex with prolonged action, benzathine bipenicillin, composed of benzathine benzylpenicillin $600000 \mathrm{IU}$, penicillin $\mathrm{G}$ procaine $300000 \mathrm{IU}$, and penicillin G sodium 300000 IU.

Each of these products was injected by the deep intramuscular route in a single dose (that is, 3 million IU of the benethamine penicillin complex and 2.4 million IU of the benzathine bipenicillin complex diluted in $6 \mathrm{ml}$ of solvent).

\section{SAMPLING}

As the long-term action of these complexes was the essential factor to be investigated, sampling began only after 48 hours. ${ }^{30}$ All the blood samples were morning fasting specimens taken at the following intervals: (a) for the benethamine penicillin complex, after 2, 3, 4, 5, and 6 days (group 1a), and after 2, 3, $4,5,6,13$, and 20 days (group 2a); and (b) for the benzathine bipenicillin complex, after $2,4,6,9,11$, and 13 days (group $1 \mathrm{~b}$ ), and after 2, 4, 6, 9, 11, 13, and 20 days (group $2 \mathrm{~b}$ ). Serum was decanted from the blood collected and the analyses performed during the following hour.
SERUM PENICILLIN MEASUREMENTS

Numerous techniques have been suggested for these measurements, as described by Chabbert ${ }^{31}$ in France and Lightbown in Britain. ${ }^{32}$ In this study, we used the method recommended by Bennet et al $^{33}$ based on the principle of gel diffusion of the penicillin from wells; this technique provides reproducible and accurate results (less than $10 \%$ error).

\section{Preparation of plates}

A sheet of plain glass measuring $400 \times 400 \times 8 \mathrm{~mm}$ was prepared by gluing glass rods along its edges; this gave an area sufficient for up to $\mathbf{8 1}$ measurements. The plate was covered with a sheet of perforated stainless steel, and the whole assembly was sterilised in dry heat.

\section{Media}

The media used were the Difco Bacto antibiotic media Nos 1 and 2, which have a $\mathrm{pH}$ of $6 \cdot 6$. They were poured in two layers to give a total thickness of $3.5 \mathrm{~mm}$. The upper layer (medium No 1) of $1 \mathrm{~mm}$ contained the test micro-organism Sarcina lutea (ATCC 93 41) in exponential growth phase, which was adjusted with a spectrophotometer to a level of $10^{6}$ bacteria $/ \mathrm{mm}^{3} \quad(\lambda=650 \mathrm{~nm})$. The serum for analysis was introduced into depressions formed in the gel, which had a capacity of $150 \mu \mathrm{l}$.

\section{Readings}

The plate prepared as described was incubated for 22 hours at $30^{\circ} \mathrm{C}$. The inhibition diameters were then read by reference to a standard range of penicillin obtained with a pool of undiluted human serum from normal subjects. A line of best fit determined by the least squares method was used to estimate the penicillin concentration.

STATISTICAL ANALYSIS

Statistical analysis was performed by the mean of the non-parametric tests of Friedmann and Mann-

TABLE I Values of the coefficients $A$ and $B$ and $r^{2}$ for the graphic estimation of the variations in serum penicillin concentrations for each of the penicillin complexes and for each of the four groups of subjects

\begin{tabular}{lllll}
\hline & \multicolumn{4}{c}{$\begin{array}{l}\text { Serum penicillin concentrations } \\
\text { (units/ml) }\end{array}$} \\
\cline { 3 - 5 } $\begin{array}{l}\text { Subject } \\
\text { group }\end{array}$ & $\begin{array}{l}\text { Penicillin } \\
\text { complex }\end{array}$ & $\begin{array}{l}\text { Coefficient } \\
A\end{array}$ & $\begin{array}{l}\text { Coefficient } \\
B\end{array}$ & $r^{2}$ \\
\hline la (Young) & $\begin{array}{c}\text { Benethamine } \\
\text { penicillin }\end{array}$ & 0.184 & -0.019 & 0.95 \\
2a (Elderly) & $\begin{array}{c}\text { Benethamine } \\
\text { penicillin }\end{array}$ & 0.229 & -0.003 & 0.79 \\
\hline 1b (Young) & $\begin{array}{c}\text { Benzathine } \\
\text { bipenicillin }\end{array}$ & 0.208 & -0.014 & 0.99 \\
2b (Elderly) & $\begin{array}{c}\text { Benzathine } \\
\text { bipenicillin }\end{array}$ & 0.510 & -0.015 & 0.92 \\
\hline
\end{tabular}




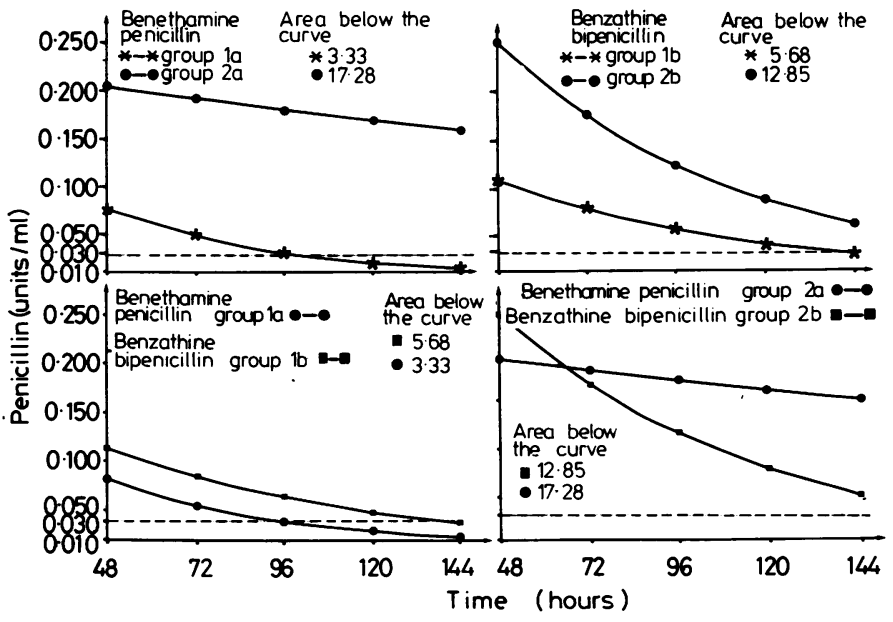

FIG 1 Regression curves of serum penicillin concentrations after a single injection of benethamine penicillin or benzathine bipenicillin in four different groups (groups Ia and $1 b$, young subjects; groups $2 a$ and $2 b$, elderly subjects). Results are in weighted values.

Whitney. ${ }^{30}{ }^{34-36}$ Friedmann's two-way analysis of variance confirmed that between the 48th and 144th hour the decrease in serum penicillin concentration was statistically significant within the same group. The model with the best fit of regression for the graphic estimation of the variations in serum penicillin concentration was the decay-type exponential function. The values of the coefficients and of $r^{2}$-that is, the proportion of total variation about the mean y explained by the regression-are presented in table I. (These coefficients were used to plot the curves shown in fig 1.)

\section{THERAPEUTIC ASSESSMENT}

As $T$ pallidum is one of the few micro-organisms which has not yet been cultivated, most of the biological notions that we have about this spirochaete have been established only by comparison with other microbial elements, which are cultivatable in vitro or with what is observed in animal experiments. ${ }^{37} 38$

Thus for penicillin to be effective in the treatment of syphilis, it was shown that the duration of the penicillinaemia should be maintained over an arbitrary minimum concentration, ${ }^{12}$ usually taken as 0.03 units of penicillin per ml of serum. ${ }^{39-42}$ For the purpose of assessing the treponemicidal action of penicillin concentrations in serum, the lethal dose was assumed to be $0.03 \mathrm{IU} / \mathrm{ml}$.

\section{Results}

\section{BENETHAMINE PENICILLIN COMPLEX}

Group la (young subjects)

After a single injection of benethamine penicillin 3 million IU in 20 young subjects (group 1a), the mean serum concentration was 0.247 units $/ \mathrm{ml} 48$ hours after injection, which is much higher than the minimum concentration regarded as treponemicidal (table II). However, $10 \%$ of these subjects had serum penicillin concentrations below this borderline $(<0.03$ units $/ \mathrm{ml})$ - that is, sublethal concentrations (fig 2). The mean concentration decreased quite rapidly in the following few days and was 0.035 units/ml on the sixth day. At that stage $40 \%$ of the group had serum penicillin concentrations of $<0.03$ units/ml (fig 2).

TABLE II Comparison of serum penicillin concentrations after injections of benethamine penicillin and benzathine bipenicillin in four different groups of subjects

\begin{tabular}{|c|c|c|c|c|c|c|c|c|c|c|c|}
\hline \multirow{2}{*}{$\begin{array}{l}\text { Subject } \\
\text { group }\end{array}$} & \multirow{2}{*}{$\begin{array}{l}\text { No in } \\
\text { group }\end{array}$} & \multirow{2}{*}{$\begin{array}{l}\text { Mean age } \\
\text { (years) }\end{array}$} & \multirow{2}{*}{$\begin{array}{l}\text { Penicillin } \\
\text { complex }\end{array}$} & \multirow{2}{*}{$\begin{array}{l}\text { Dose } \\
\text { (IU) }\end{array}$} & \multicolumn{7}{|c|}{ Mean serum penicillin concentrations (units $/ \mathrm{ml}$ ) at: } \\
\hline & & & & & 2 Days & 3 Days & 4 Days & 5 Days & 6 Days & 13 Days & 20 Days \\
\hline & 20 & $20 \cdot 5$ & $\begin{array}{l}\text { Benethamine } \\
\text { penicillin }\end{array}$ & $3 \times 10^{6}$ & 0.247 & 0.139 & 0.078 & 0.053 & 0.035 & & \\
\hline 2a (Elderly) & 36 & 75 & $\begin{array}{l}\text { Benethamine } \\
\text { penicillin }\end{array}$ & $3 \times 10^{6}$ & 0.488 & 0.421 & 0.351 & $0 \cdot 390$ & 0.342 & $0 \cdot 104$ & 0.042 \\
\hline lb (Young) & 15 & 22 & $\begin{array}{l}\text { Benzathine } \\
\text { bipenicillin }\end{array}$ & $2.4 \times 10^{6}$ & $0 \cdot 340$ & & 0.161 & & 0.080 & 0.037 & \\
\hline 2b (Elderly) & 25 & 76 & $\begin{array}{l}\text { Benzathine } \\
\text { bipenicillin }\end{array}$ & $2 \cdot 4 \times 10^{6}$ & 0.635 & & 0.216 & & $0 \cdot 151$ & 0.081 & 0.064 \\
\hline
\end{tabular}



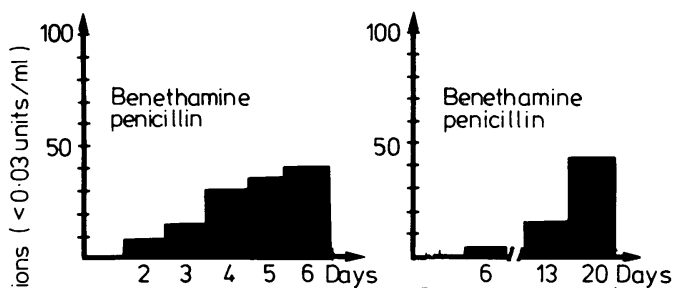

Young subjects (group 1a)
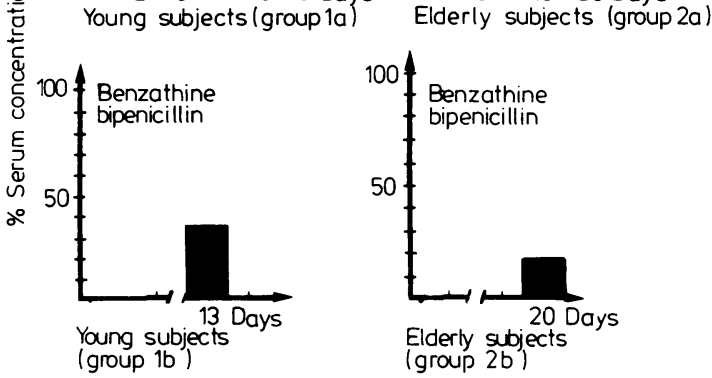

FIG 2 Percentage of mean serum penicillin concentrations $<0.03$ units $/ \mathrm{ml}$ in four groups of subjects.

\section{Group 2a (elderly subjects)}

After the same dose of benethamine penicillin in $\mathbf{3 6}$ elderly subjects (group 2a) the mean serum concentration after 48 hours was 0.488 units $/ \mathrm{ml}$, which was much higher than the figure for group la; none of these subjects had a sublethal concentration. These concentrations also decreased but more slowly than in the young subjects; at 20 days after the injection the mean concentration was 0.042 units $/ \mathrm{ml}$. Nevertheless, by this time $43 \%$ of this older group had serum penicillin concentrations below the treponemicidal concentration (fig 2).

\section{Statistical analysis}

The statistical results are presented in table III and fig 1. For each time interval the serum penicillin concentrations were significantly higher $(\mathrm{P}<0 \cdot 0001)$ in the elderly subjects (group $2 a$ ). Thus after 48 hours the mean concentrations were twice as high in elderly as in young subjects. The two curves then fell almost in parallel, although the serum concentrations in the elderly subjects remained well above the lethal concentrations for $T$ pallidum and for a much longer period (20 days instead of six). Moreover, the proportion with a sublethal concentration $(<0.03$ units $/ \mathrm{ml}$ ) reached $40 \%$ in young subjects after six days but in elderly subjects only after 20 days.

\section{BENZATHINE BIPENICILLIN COMPLEX Group lb (young subjects)}

After a single injection of benzathine bipenicillin $2 \cdot 4$ million IU (that is, 600000 IU less than the dose of benethamine penicillin) in 15 young subjects (group 1b), the mean serum penicillin concentration was $0 \cdot 340$ units $/ \mathrm{ml}$ after 48 hours (table II). None of this group had a serum concentration $<0.03$ units $/ \mathrm{ml}$ on

TABLE III Variations in serum penicillin concentrations after injection of benethamine penicillin or benzathine bipenicillin in four groups of subjects*

Serum penicillin concentrations (units/ml) $\dagger$ at (hours):

\begin{tabular}{|c|c|c|c|}
\hline \multirow[b]{2}{*}{ Statistical comparisons } & & & \\
\hline & 48 & 96 & 144 \\
\hline $\begin{array}{l}\text { Benethamine penicillin } \\
\text { Group 1a (young) } \\
\text { Group 2a (elderly) } \\
\text { Z¥ } \\
\text { P }\end{array}$ & $\begin{array}{l}0 \cdot 079 \pm 0 \cdot 011 \\
0 \cdot 210 \pm 0 \cdot 028 \\
4 \cdot 360 \\
<0 \cdot 0001\end{array}$ & $\begin{array}{l}0 \cdot 027 \pm 0 \cdot 004 \\
0 \cdot 166 \pm 0 \cdot 021 \\
5 \cdot 765 \\
<0 \cdot 0001\end{array}$ & $\begin{array}{l}0 \cdot 011 \pm 0 \cdot 004 \\
0 \cdot 159 \pm 0 \cdot 034 \\
5 \cdot 546 \\
<0 \cdot 0001\end{array}$ \\
\hline $\begin{array}{l}\text { Benzathine bipenicillin } \\
\text { Group 1b (young) } \\
\text { Group 2b (elderly) } \\
\text { Z尹 } \\
\text { P }\end{array}$ & $\begin{array}{l}0 \cdot 110 \pm 0 \cdot 013 \\
0 \cdot 281 \pm 0 \cdot 038 \\
3 \cdot 716 \\
0 \cdot 0001\end{array}$ & $\begin{array}{l}0.052 \pm 0.004 \\
0.097 \pm 0.012 \\
2 \cdot 067 \\
0.02\end{array}$ & $\begin{array}{l}0 \cdot 029 \pm 0.003 \\
0 \cdot 068 \pm 0.008 \\
3 \cdot 450 \\
0 \cdot 0003\end{array}$ \\
\hline $\begin{array}{l}\text { Groups } 2 a \text { and } 2 b \\
\text { Benethamine penicillin } \\
\text { Benzathine bipenicillin } \\
Z \neq \\
\mathrm{P}\end{array}$ & $\begin{array}{l}0 \cdot 210 \pm 0 \cdot 028 \\
0 \cdot 281 \pm 0 \cdot 038 \\
1 \cdot 410 \\
\mathrm{NS}\end{array}$ & $\begin{array}{l}0 \cdot 166 \pm 0 \cdot 021 \\
0 \cdot 097 \pm 0 \cdot 012 \\
2 \cdot 579 \\
0 \cdot 005\end{array}$ & $\begin{array}{l}0 \cdot 159 \pm 0.033 \\
0 \cdot 068 \pm 0 \cdot 008 \\
3 \cdot 053 \\
0 \cdot 001\end{array}$ \\
\hline $\begin{array}{l}\text { Groups } I a \text { and } 2 a \\
\text { Benethamine penicillin } \\
\text { Benzathine bipenicillin } \\
Z \neq \\
P\end{array}$ & $\begin{array}{l}0 \cdot 079 \pm 0 \cdot 011 \\
0 \cdot 110 \pm 0 \cdot 013 \\
2 \cdot 283 \\
0 \cdot 01\end{array}$ & $\begin{array}{l}0 \cdot 027 \pm 0 \cdot 004 \\
0 \cdot 052 \pm 0 \cdot 004 \\
3 \cdot 383 \\
0 \cdot 0005\end{array}$ & $\begin{array}{l}0 \cdot 011 \pm 0 \cdot 004 \\
0 \cdot 029 \pm 0 \cdot 003 \\
3 \cdot 534 \\
0 \cdot 0002\end{array}$ \\
\hline
\end{tabular}

* Results in weighted values

t Mean \pm error of mean

₹ Number of standard normal variates 
the second day. On the thirteenth day the mean concentration was 0.037 units $/ \mathrm{ml}$ but by that time $33 \%$ of the subjects had sublethal concentrations (fig 2).

\section{Group $2 b$ (elderly subjects)}

After the same dose of benzathine bipenicillin in 25 elderly subjects (group $2 \mathrm{~b}$ ), the mean serum concentration was 0.635 units/ml after 48 hours-that is, twice the figure observed in the younger group (group 1b); none of these subjects had a concentration below the minimum concentration regarded as treponemicidal. On the other hand, the concentration then decreased much more rapidly until the twentieth day when the mean serum concentration was 0.064 units $/ \mathrm{ml}$ and $20 \%$ of the subjects had a concentration $<0.03$ units $/ \mathrm{ml}$ (table II and fig 2).

\section{Statistical analysis}

The statistical analyses of the mean weighted values are shown in table III and fig 1 . These values indicated that the serum penicillin concentrations were significantly higher $(P<0.02)$ in the elderly subjects (group 2b) but, unlike with benethamine penicillin, the values tended to converge rapidly. Thus, $\mathbf{4 8}$ hours after the injection the elderly subjects again had concentrations twice as high as the young subjects, but the serum penicillin curve fell much more quickly after that in the former group, although it consistently remained above the curve in young subjects on the thirteenth day but in only $20 \%$ of elderly subjects, at least under the conditions of our experiment.
COMPARISONS BETWEEN PENICILLIN

\section{COMPLEXES}

Groups $1 a$ and $1 b$ (young subjects)

Although the dose of benethamine penicillin injected was $600000 \mathrm{IU}$ greater than the dose of benzathine bipenicillin ( 2.4 million IU), the mean concentrations found after $\mathbf{4 8}$ hours were lower for the former preparation than for the long-acting penicillin (table II, fig 3). The two curves then fell in parallel to reach the minimum treponemicidal limit after about five days with benethamine penicillin and after 13 days with benzathine bipenicillin. At these two points in time the percentages of sublethal concentrations were $33 \%$ for benzathine bipenicillin and $40 \%$ for benethamine penicillin (fig 2). The mean serum weighted concentrations and the calculated value of $Z$ (the number of standard normal variates) are given in table III and fig 1. These show that the mean serum concentrations for the benzathine bipenicillin complex were significantly higher between the 48th and 144th hours than those observed after injection of a single dose of 3 million units of the benethamine penicillin complex.

\section{Groups $2 a$ and $2 b$ (elderly subjects)}

Forty-eight hours after the injection of benzathine bipenicillin, the long-acting penicillin complex, the mean concentrations were much higher in the elderly subjects (group 2b) than those observed after the injection of benethamine penicillin (table II). However, while the curve of mean concentrations for the latter preparation fell slowly, indicating a longer duration, the curve for benzathine bipenicillin fell

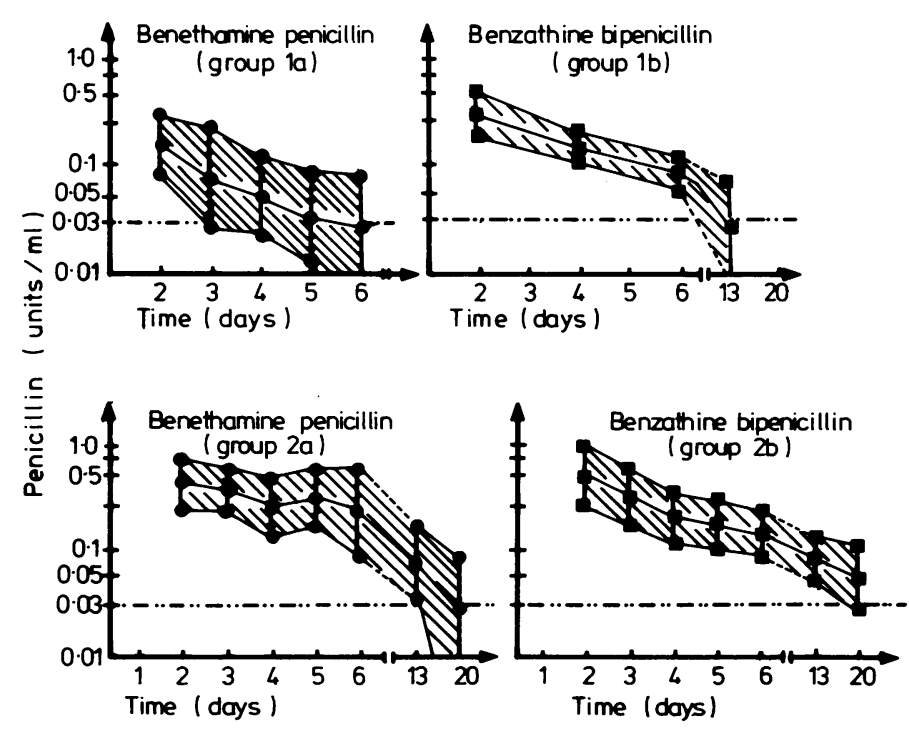

FIG 3 Graphs of the mean serum concentrations of benethamine penicillin and benzathine bipenicillin in four groups of subjects (groups $1 a$ and $1 b$, young subjects; groups $2 a$ and $2 b$, elderly subjects). 
much more rapidly and crossed the other curve after about three days, so that the serum concentrations were lower than those obtained with the mediumlong-acting penicillin (benethamine) (fig 3).

As before, the mean serum concentration and the calculated value of $Z$ are presented in table III and fig 1. Analysis of these results showed that after a single injection of 2.4 million IU of benzathine bipenicillin or 3 million IU of benethamine penicillin, the penicillin concentrations were very similar after 48 hours (no statistically significant difference) but subsequently became significantly higher for benethamine penicillin.

\section{Discussion}

Many factors are known to affect the action of drugs in the body; the processes of absorption, distribution, localisation in tissues, biotransformations, and excretion ${ }^{43-45}$ consequently make a difference in their bioavailability. Some of these factors depend on physicochemical properties of the formulations; others are individual factors, such as weight, size, body surface, genetic factors, race, sex, and age. 18252846 We therefore considered that it would be interesting in this study to take into account only the age factor, which covers all these variations. Age modifies the kinetics of antibiotics. In children, as in elderly subjects, the serum concentrations of these products are higher than those observed in adults. ${ }^{47-50}$

Investigations on penicillin carried out with shortacting penicillins (those eliminated within a few hours) prescribed in a single dose, whatever the route of administration, corroborated our results.

Molholm-Hansen et al ${ }^{19}$ demonstrated that after the injection of $600 \mathrm{mg}$ ( 1 million IU) by the intravenous route the half-life of penicillin $G$ in old people was twice the figure observed in young adults. Simon et $a l^{20}$ confirmed these results in a study of 1 million units of propicillin given orally to young and old people. The same difference was observed by Leikola and Vartia ${ }^{21}$ with penicillin $G$ and procaine penicillin, by Clini et $a^{22}$ with ampicillin, and by Bouchon ${ }^{23}$ after an intramuscular injection. Thus, penicillins with short elimination ( $<24$ hours), as well as longacting penicillins, are found at higher concentrations in the serum of elderly subjects than in that of young people.

It is an important factor that with increasing age all the functional capacities (respiratory, cardiac, and renal) are progressively being reduced. There is a more or less linear decrease of organic functions in old people. ${ }^{48}$ Tissues are modified both in quality and quantity; the adipose tissue is increased and the body water (total, extracellular and intracellular) is reduced. As metabolically active tissues are progressively diminishing, the physical and biochemical compositions of quantitatively important tissues (such as the connective tissue) are modified ${ }^{51}$; the apparent volume of distribution is changed. The fixation on proteins $s^{52-54}$ and on red blood cells ${ }^{55}$ is modified. The metabolism and the elimination of drugs are different. ${ }^{44} 51$

On the other hand, in this study, when serum concentrations produced by $2 \cdot 4$ million IU of benzathine penicillin complex are compared with those produced by 3 million IU of benethamine penicillin complex, it appeared that with the latter (a) the sublethal concentrations were reached more quickly in young subjects; (b) penicillin concentrations $<0.03$ units $/ \mathrm{ml}$ occurred sooner and more frequently (table II, figs 2 and 3 ); (c) the results of the penicillinaemia obtained were more dispersed about the mean (table II); (d) in weighted values the mean deviations in young subjects were homogeneous and comparable with those obtained with the benzathine penicillin complex (table III) while in elderly subjects variations were observed (table II) for both complexes; (e) the kinetics of elimination of both complexes were comparable in young subjects while in elderly subjects the benethamine penicillin complex followed a slower kinetic of elimination giving higher penicillin concentrations in serum for a longer period than the benzathine penicillin complex; and (f) treatment regimens based solely on the number of international units of penicillin were precarious if the properties of the chosen salts of penicillin were not taken into account.

According to work carried out on Gram-positive organisms and reported by Tinelli, ${ }^{56}$ penicillin acts on growing organisms on the cell wall; the transpeptidase, involving the formation of interpeptidic bridges which fasten the reticulated structure of the cell wall, is inhibited. The growing bacteria then begin to swell and form protoplasts, which lyse as a result of osmotic pressure. Although $T$ pallidum is not cultivatable in vitro the mechanism of the action of penicillin is considered to be the same (Luger A, paper read at the 14th International Congress of Dermatology, Venice, 1972; Kern A, personal communication, 1973)..$^{57}$

Based on this hypothesis, principles of standard penicillin treatment of early syphilis were established on the following syllogism: (a) all treponemes would divide every 30-33 hours ${ }^{42}$; (b) penicillin acts on these organisms when they divide (Kern A, a personal communication, 1973) ${ }^{2} 57$ and when this antibiotic has risen to a concentration of 0.03 units $/ \mathrm{ml}$ in serum $^{39} 41$ 42; $^{2}$ and (c) therefore such a serum concentration maintained for 7-10 days is considered 
adequate to kill all the $T$ pallidum which have invaded an organism. ${ }^{2}$

The results of our study have shown that for young subjects, with the standard dosages generally used in the treatment of syphilis when one or other of these complexes is used, it would be preferable to use benzathine bipenicillin, assuming the minimum active penicillin concentration to be 0.03 units $/ \mathrm{ml}$. But if we refer to the work of Eagle et al ${ }^{58}$ the mean active concentration of penicillin in rabbits would be between 0.0083 units $/ \mathrm{ml}$ and 0.0167 units $/ \mathrm{ml}$, but the effective concentration would be much higherthat is, 0.6 units $/ \mathrm{ml}$, an amount which is rarely attained with the two standard posologies used.

If it is admitted that a serum concentration of 0.03 units of penicillin per $\mathrm{ml}$ should be maintained for 7-10 days, it appeared that the benzathine bipenicillin complex did not give an adequate safety margin covering possible individual variations and the lack of direct relationship between serum concentrations and the therapeutic effect. ${ }^{59-61}$

Since most of the $T$ pallidum are disseminated very quickly in the organism, ${ }^{62}$ it seems unlikely that they would divide all together at the same time ${ }^{37} 57$ and continuously at the same rhythm during the first days of the experimental infection, ${ }^{62}$ since the multiplication time (30-33 hours) has been estimated at the local area of inoculation during the incubation period and in optimum conditions. ${ }^{42}$

This study corroborates the principle that the therapeutic activity is conditioned by the ability to keep an adequate concentration of the active part of the drug at the focus of infection for an adequate period of time; however, it must be noted that these therapeutic dosages given in a single injection do not allow any safety margin, ${ }^{12}$ particularly as we do not have an absolute criterion which allows us to assert that all $T$ pallidum have really been destroyed. ${ }^{37}$

It therefore appears from our results that it is not possible to achieve $100 \%$ bacteriological sterilisation in young subjects; dosages of this kind might be sufficient to heal a chancre but not to cure the host, which has been invaded by treponemes for a certain time, as we have proved ${ }^{63}{ }^{64}$ and as has been confirmed by others. ${ }^{65} 66$

Consequently, in the treatment of syphilis, a standard dose consisting of a single injection of a penicillin product (medium-long-acting or longacting) should lead to a substantial number of therapeutic failures which seem to be due to the low dosages injected, which allow no safety margin.

In this respect, the selection of a treatment schedule should depend on the practical circumstances of the patient, as well as on the medical considerations, provided the dose/time principle is known and followed. ${ }^{2}$
We wish to thank Professor M Bolgert and Dr Garrel for their invaluable help, and S Burtchaell for his kind co-operation. Dr $\mathbf{J}$ Durel carried out the statistical analysis of the results.

\section{References}

1. Willcox, RR. Treatment of early venereal syphilis. $B r J$ Vener Dis 1962;38: 109-23.

2. Idsфe O, Guthe T, Willcox RR. Penicillin in the treatment of syphilis. Bull WHO 1972;47 suppl: 5-68.

3. Neuman M. Vade-mecum des Antibiotiques et Agents Chimiothérapiques Anti-infectieux. 1st and 4th ed. Paris: Maloine, 1962, 1979.

4. Thompson SE, Wiesner PJ, Sanford JP. Why review syphilis therapy now? J Amer Ven Dis Assoc 1972;3, No 2 (part 2): 48 .

5. Nelson MG, Talbol JM, Binns TB. Benethamine penicillin: a new salt with a prolonged action. Br Med J 1954; ii:339-41.

6. Bash B, Ireland DM, Thorn AG, Tomich EG. The pharmacological properties of benethamine penicillin. Antibiot Chemother 1955;5: 152-61.

7. Huriez C, Desmons F, Fossati-Delescluse, R. Etude thérapeutique et métabolique de la bénéthamine-pénicilline. Bull Soc Fr Dermatol Syphilol 1964;71:643-4.

8. Szabo JL, Edwards CD, Bruce WF. N-N'dibenzylethylenediamine penicillin G: preparation and properties. Antibiot Chemother 1951; 1:499-503.

9. Rein CR, Buckwalter FH, Mann C, Landy SE, Flax S. Timedosage relationship in the treatment of treponemal diseases with a new combination of three penicillin salts. Laboratory and clinical basis for effective therapy. $J$ Invest Dermatol 1953;21:435-46.

10. Tinkler AE, Shannon R. Daily penicillin serum concentrations following injection of $\mathbf{2 \cdot 4}$ megaunits of "all-purpose" penicillin. Bull WHO 1966;35:857-62.

11. Graciansky $P$ de, Grupper $C$. Résultats du traitement de la syphilis primo-secondaire par l'injection unique de pénicilline long-retard (à propos de 147 malades). Bull Soc Dermatol Syphilol 1959; 5:699-710.

12. Graciansky $\mathbf{P}$ de, Grupper $C$. La bénéthamine dans le traitement des syphilis récentes. Bull Soc Dermatol Syphilol 1963;70:17.

13. Brown WJ. Syphilis and gonorrhea in general practice. Clin Med Winnetka 1962; 69:91-100.

14. Siboulet A, Busquet PY, Egger L, Majewski E. Gonococcie et syphilis. Bull Soc Dermatol Syphilol 1973;80:642-5.

15. United States Public Health Service. Syphilis: Modern Diagnosis and Management. Washington DC: US Department of Health, Education and Welfare, 1960.

16. United States Public Health Service. Syphilis: A Synopsis. Public Health Service Publication No 1660. US Department of Health, Education and Welfare 1968:110-6.

17. United States Public Health Service. Center for Disease Control recommended treatment schedules for syphilis. Curr Lit Vener Dis 1976; 1:8-10.

18. Dayer P, Balant L. La pharmacologie clinique pourquoi? Med Hyg 1978; 36:997-8.

19. Molholm-Hansen J, Kampmann J, Laursen H. Renal excretion of drugs in the elderly. Lancet 1970; i: 1170.

20. Simon C, Malerczykiv V, Muller U, Muller G. Zur pharmakokinetik von propicillin bei geriatrischen patienten in vergleich zujungeren eerwaschsenen:' Dtsch Med Wochenschr 1972;52: 1999-2003.

21. Leikola E, Vartia KO. On penicillin levels in young and geriatric subjects. J Gerontol 1957; 12:48-52.

22. Clini V, Mars G, Tansini G. La distribuzione di alcuni antibiotici in soggeti di varia eta. La Settimana Medica 1964;52: 1007-24.

23. Bouchon JP. L'emploi des antibiotiques chez les vieillards. In: Bourlière F, ed. Progrès en Gerontologie. Paris: Editions Médicales Flammarion 1969:249-263.

24. Food and Drug Administration. Proposed bioavailability requirements. Federal Register 1973; 38: 885-7.

25. Chodos DJ, Disanto AR. Basics of bioavailability and description of Upjohn single dose study design. Upjohn Company Ed. Kalamazoo, Michigan; Upjohn Co, 1974. 
26. Hirtz J. La disponibilité biologique des médicaments. Actual Pharmacol 1976; 28:76-106.

27. Dagher et al. Nomogramme pour la détermination des volumes sanguin, plasmatique et globulaire à partir de l'âge et du poids corporel de l'adulte. Adv Surg 1965;1:69.

28. Hirtz J, Schoeller JP. Intérêt clinique du dosage des médicaments dans le sang. Nouv Presse Med 1976;5: 869-72.

29. Singlas E. Biodisponibilité. In: Giroud JP, Mathé G, Meyneil G, eds. Pharmacologie Clinique. Paris: Expansion Scientifique 1978: 119-35.

30. Schumacher GE. Practical pharmacokinetic techniques for drug consultation and evaluation: Use of dosage regimen calculations. Am J Hosp Pharm 1972; 29:474-84.

31. Chabbert $\mathbf{Y}$, Boulingre $\mathrm{H}$. Modifications pratiques concernant le dosage des antibiotiques en clinique. Rev Fr Etudes Clin Biol 1957; 1:636-40.

32. Lightbown JW. Svlitzeanu D. The assay of penicillin in bloodserum using Sarcina lutea. Bull WHO 1957; 17:553-67.

33. Bennet JV, Brodie JL, Benner EJ, William MMK. Simplified accurate method for antibiotic assay of clinical specimens. Appl Microbiol 1966; 14: 170-7.

34. Bliss CI. In: Statistics in Biology. New York: McGraw Hill Inc, 1970.

35. Brogard JM, Pinget $M$, Dorner $M$, Lavillaureix $J$. Etablissement du profil pharmacocinétique d'un antibiotique. Intérêt pratique et applications à l'étude comparative des céphalosporines. Bull Inst Pasteur 1976; 74: 383-412.

36. Conover WJ. In: Practical Non-parametric Statistics. New York: John Wiley and Son Inc, 1976.

37. Collart P. Critique des éléments de base sur lesquels reposent certains traitements de la syphilis. Sem Hop 1974; 50:673-9.

38. Eagle H, Magnuson HJ, Fleischman R. Relation of the size of the inoculum and the age of the infection to the curative dose of penicillin in experimental syphilis with particular reference to the feasibility of its prophylactic use. J Exper Med 1947;85:423-40.

39. Eagle $\mathbf{H}$. Speculations as to the therapeutic significance of the penicillin blood level. Ann Intern Med 1948;28:260-78.

40. Eagle $H$. The dynamics of penicillin action to its use in the treatment of syphilis. Recapitulation of the experimental data. In: Symposium on Current Progress in the Study of Venereal Diseases. Washington DC: Division of Venereal Diseases, United States Public Health Service, 1949:272-6.

41. Magnuson HJ. The use of antibiotic in spirochaetosis laboratory and general considerations. $\mathrm{Am} \mathrm{NY} \mathrm{Acad} \mathrm{Sci}$ 1952;55:1161-7.

42. Turner TB, Hollander MD. Biologie des tréponématoses. Monograph Series No 35. Geneva: WHO, 1957.

43. Eben-Moussi E, Van den Driessche J. Pharmaco-cinétique des antibiotiques dans l'organisme humain. Anest Anal Réan 1971;28:671-87.

44. Boissier JR, Advenier C. Résorption des médicaments. Concours Médical 1976;98:6613-73.

45. Benazet F, Dubost M, Jolles G, Leau O, Pascal C Preud'Homme J, Terlain B. Liaisons et modifications des antibiotiques in vivo (sang et foyer infectieux). Biol Med 1968;57: 1-26.
46. World Health Organisation. Biodisponibilite des médicaments: Principes et problèmes. WHO Tech Rep Ser 1974; No 536.

47. Gladtke E. Pharmacokinetics in relation to age. Boll Chim Farm 1973; 112:333-41.

48. Vignalou J. Généralités sur la thérapeutique en gériatrie. Cah Med 1974; 15 (9), 573-8.

49. Bender AD, Pharmacodynamic principles of drug therapy in the aged. J Am Geriatr Soc 1974;22:296-303.

50. Gorrod JW. Absorption, metabolism and excretion of drugs in geriatric subjects. Clin Gerontol 1974; 16:30-42.

51. Paychere JM Géronto-pharmacologie. Médecine et Hygiène 1978; 36: 1043-53.

52. Kunin CM. Clinical pharmacology of the new penicillin. I: The importance of serum protein binding in determining antimicrobial activity and concentration in serum. Clin Pharmacol Ther 1966; 7:166-79.

53. Rolinson GN. The significance of protein binding of antibiotics in vitro and in vivo. In: Waterson AP, ed. Recent Advances in Medical Microbiology, Chap 7. London: J \& A Churchill, 1967:254-83.

54. Wallace S, Whiting B, Muncio J. Factors affecting drug binding in plasma of elderly patients. Br J Clin Pharmacol 1976; 3:327-30.

55. Chan K, Kendall MJ, Ritchard M, Welles WDE, Wickers MD. The effect of aging on plasma pethidine concentration. $\mathrm{Br} J$ Clin Pharmacol 1975; 2: 197-302.

56. Tinelli R. Le glycopeptide des parois bactériennes. Bull Inst Pasteur 1968; 66: 2507-38.

57. Luger A. Diagnostik und therapie der syphilis. Med Klin 1971; 66: 339-43.

58. Eagle $H$, Fleischman $R$, Musselman AD. The effective concentration of penicillin in vitro and in vivo for streptococci, pneumococci and Treponema pallidum. $J$ Bacteriol 1950;59:625-43.

59. Heite HJ. Beitrag zur verteilung des penicillins im savgetierorganismus. Klin Wochenschr 1952; 30: 174-5.

60. Anonymous. Oral penicillins, blood levels, antimicrobial sensitivity and clinical effectiveness. JAMA 1961;175:607-8.

61. Balant L, Dayer P. Il n'y a pas de relation entre les taux sanguins et l'effet du médicament. Médecine et Hygiene 1978; 36: 1029-38.

62. Collart $\mathrm{P}$. Le tréponème pâle. Rev Méd 1970;11:1265-300.

63. Collart $P$, Poitevin $M$. Le problème des tréponèmes pénicillinorésistants. Sem Hop Paris 1975; 51:1489-96.

64. Collart P, Poitevin M. Données récentes sur le comportement des tréponèmes pâles. Revue du Praticien (Paris) 1976; 26:4065-76.

65. Giles AJM, Lawrence AG. Treatment failure with penicillin in early syphilis. Br J Vener Dis 1979;55:62-4.

66. Lanigan-O'Keeffe FM. Monorecidive or chancre redux. $\mathrm{Br} \mathrm{J}$ Clin Pract 1978;82:206-7. 